\title{
シンポジウム記録 水圏生物タンパク質科学の新展開
}

\section{II-3. 魚介類の毒素タンパク質}

長島裕二，桐明 絢

東京海洋大学食品生産科学部門

II-3. Proteinaceous toxins of venomous scorpaeniform fish

YuJI NAGASHMA AND AYA KIRIAKE

Department of Food Science and Technology, Tokyo University of Marine Science and Technology, Minato, Tokyo 108-8477, Japan

\section{1. タンパク質毒素と魚介類}

毒はごく少量で特定組織の標的細胞や分子に特異的な 作用を与える特殊な機能性分子である。魚介類にも毒を もつものが多いが，毒素タンパク質が明らかになってい る例は少ない。その原因は，魚介類の毒素タンパク質が 非常に不安定で取り扱いが難しく, 目的タンパク質の精 製が極めて困難なため, 構造決定や性状解明が行えない からである。

\section{2. カサゴ目刺毒魚のタンパク質毒素}

魚類の中には, エイ類, ナマズ類, カサゴ類, アイゴ 類など，鯺に毒腺または毒囊が付随した刺棘を有する刺 毒魚が存在している。特に，カサゴ目フサカサゴ科のミ ノカサゴ，オニオコゼ科のオニオコゼ，オニダルマオコ ゼ類，八オコゼ科の八オコゼなどが知られている。これ らの毒素は，低温保存中にさえ失活してしまうことが多 いが，オニダルマオコゼ類の毒素は比較的安定で，ツノ ダルマオコゼから stonustoxin (SNTX)，オニダルマオ コゼから neoverrucotoxin (neoVTX) と命名された毒 素が精製され，いずれもアミノ酸約 700 残基をもつ $\alpha$ サブユニットと $\beta$-サブユニットからなるへテロ二量体 タンパク質であることが明らかにされた。両毒素の配列 相同性は高く, マウス致死活性, ウサギ赤血球に対する 特異的溶血活性, 浮腫形成活性などの生理活性が酷似し ていた。

一方，ミノカサゴ類（ネッタイミノカサゴ，ミノカサ ゴ，八ナミノカサゴ）の刺毒は，マウス致死活性とウサ ギ赤血球に対する特異的な溶血活性をもち，SNTXや neoVTX と性状が類似していた。また，ツノダルマオ コゼ粗毒に対する抗血清でミノカサゴ類刺毒の毒性が中 和され，イムノブロットで抗原交差性が確認されたこと から，SNTX や neoVTX とミノカサゴ類の刺毒は構造
上の類似性が強く示唆された。

しかし，ミノカサゴ類刺毒は非常に不安定なため, ク ロマトグラフィーによる精製は困難であった。そこで, オニダルマオコゼ類毒素との構造類似性に着目して, 遺 伝子情報をもとに cDNA クローニングを行い，ミノカ サゴ，ネッタイミノカサゴ，八ナミノカサゴ，オニオコ ゼ，八オコゼの刺毒の一次構造が決定された。いずれも SNTX 打よび neoVTX と同様，アミノ酸約 700 残基か

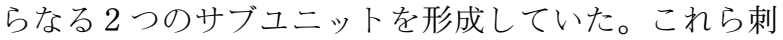
毒の立体構造や活性部位の特定は今後の研究課題である が，魚類刺毒タンパク質の一次構造に基づいて作成され た分子系統樹から，毒素はフサカサゴ科からオニオコゼ 科抢よびハオコゼ科へ， サブユニットは $\beta$ から $\alpha$ へ派 生し，カサゴ目魚類刺毒はフサカサゴ科 $\beta$ サブユニッ 卜を基点として進化したと考えられる。

\section{3. 毒拡散因子としてのヒアルロニダーゼ}

ヒアルロニダーゼは組織外マトリクスのヒアルロン酸 を加水分解する酵素で，へビ，サソリ，八チなどの毒液 中に含まれている。ヒアルロニダーゼ自体に毒性はない が, 組織を軟化, 破壊して毒素の拡散を助長すると考え られている。

魚類刺毒のヒアルロニダーゼは, 淡水エイ, ミノカサ ゴ類, オニダルマオコゼ類, 八オコゼ類から検出されて いる。そのうち，ネッタイミノカサゴ，八ナミノカサ ゴ，ツノダルマオコゼ，オニダルマオコゼのヒアルロニ ダーゼのアミノ酸配列が決定され，それらの配列相同性 は高かった。これら 4 種のヒアルロニダーゼは, 基質 としてヒアルロン酸を特異的に加水分解し, 至適温度 $\left(37^{\circ} \mathrm{C}\right)$ と至適 $\mathrm{pH}(6.0 \sim 6.6)$ は一致していた。へビや 八チのヒアルロニダーゼはヒトにアナフィラキシー ショックを起こすアレルゲンであると報告されており, 広義では “毒” となるのかもしれない。しかし，魚類刺 毒中のヒアルロニダーゼのアレルギー作用は不明である。

\section{4. 今後の展望}

これまで毒素を抽出, 精製して構造解析することが困 難であった魚介類の毒素タンパク質について，バイオイ ンフォマティクスを活用することにより, カサゴ目刺毒 魚のタンパク質毒素の一次構造が決定された。しかし， エイ類やナマズ類の毒素については, 依然として本体が 不明なままである。海洋生物毒は独自の構造と活性を示 すものが多く, 今後, 機能性タンパク質研究が期待され る分野である。 